\title{
ANALISIS PERAN HUMAS PEMERINTAH DAERAH PROVINSI BENGKULU DALAM MENJALANKAN HUBUNGAN DENGAN PERS (Studi pada Dinas Perhubungan, Komunikasi dan Informatika Provinsi Bengkulu)
}

\author{
Oleh : \\ Yetti Herawati, Linda Astuti, Maryaningsih
}

\begin{abstract}
Government Public Relations could serve as a means or channel of government agencies in running relationship with the press, including the Local Government of Bengkulu province. This study aimed to see at how public relations play this role. The method used in this research was descriptive qualitative method in which the data collection was conducted by semistructured interviews to research subjects. It's possible for researchers to develop questions appropriate to the situation and condition so it was possible to get complete data. From the research, the role of $P R$ in the Bengkulu Provincial Government ran good relationship with the press. The good role of the public relations could be demonstrated by the implementation of most of the series of activities such as: building and maintaining a good relationship with the press, served and understood the media, press interviews, broadcast rebuttal, filling out the important public section in the press, and documentation.
\end{abstract}

\section{Keywords : Public Relation Role, Mass Media Relation}

\section{PENDAHULUAN}

Humas merupakan salah satu unsur penting dalam suatu badan atau organisasi, ia memainkan peran yang sangat penting dalam sebuah organisasi atau pemerintahan. Ia tidak saja menjadi tulang punggung dalam membangun citra positif organisasi dan pemerintahan, ia juga bertugas mencapai reputasi yang prestise (Ruslan,2000:90). Hal ini dikarenakan peran yang dimainkan secara sistematik, mengevaluasi sikap dan tingkah laku publiknya, mampu mengidentifikasi berbagai masalah ditengah dinamika masyarakat yang berkembang, serta menjaga sikap kepentingan publik yang beragam dan menjalankan program aksi sebagaimana pemahaman dan keinginan publiknya (Effendy, 1993.65)

Pers dinilai memiliki kekuatan untuk mempengaruhi opini khalayak. Pers mampu membantu menimbulkan citra positif pihak-pihak yang diberitakanya.
Opini dan citra khalayak bisa muncul sangat positif, bisa pula sangat negatif. Citra positif muncul karena isi pesan yang positif, dan orang atau lembaganya cenderung menyenangi jika diri atau lembaganya muncul dalam media masa dengan citra yang positif. Sedangkan citra negatif muncul karena pesan yang muncul pun negatif, dan orang pun enggan diberitakan negatif. Oleh karena itu peranan pers sangat besar bagi suatu lembaga atau perusahaan, begitupun bagi individu atau perorangan.

Peranan Humas Pemerintahan dapat merupakan bagian suatu alat atau saluran instansi pemerintah (The Public Relations are functional as a tools or channels of goverment publication activity), yaitu untuk memperlancar proses interaksi positif dan penyebarluasan informasi mengenai publikasi pembangunan nasional atau daerah provinsi melalui kerjasama dengan pihak media atau pers, baik menggunakan saluran 
media elektronik maupun media cetak lainnya (Ruslan, 2000.96-97).

Bertitik tolak dari uraian di atas dapat dikatakan bahwa Humas sangat berperan penting dalam menjalankan hubungan dengan pers, begitu pun sebaliknya, dimana antara Humas dan pers saling membutuhkan. Dengan demikian inti hubungan dengan pers itu adalah proses memberi dan melayani, bukannya meminta sesuatu yang harus dijalani oleh para petugas Humas. Oleh karena itu penulis tertarik untuk meneliti peranan humas pemda provinsi Bengkulu khususnya dinas perhubungan komunikasi dan informatika, dalam menjalankan hubungan dengan pers. Adapun tujuan dari penelitian ini adalah untuk mengetahui peranan Humas Pemda Propinsi Bengkulu dalam menjalankan hubungan dengan pers.

\section{METODE PENELITIAN}

Metode yang digunakan dalam penelitian ini adalah metode kualitatif deskriptif, yaitu suatu metode penelitian yang hanya memaparkan situasi atau peristiwa. Dapat juga diartikan melukiskan variabel demi variabel, satu demi satu. Penelitian ini tidak mencari atau menjelaskan hubungan, tidak menguji hipotesis atau membuat prediksi (Rakhmat, 2000.24). Penelitian ini juga bertujuan untuk menggambarkan apa yang terjadi, apa yang terasa dan apa yang menggejala sesuai dengan keadaan sesungguhnya.

Teknik sampling yang digunakan adalah purposive sampling yaitu pemilihan sampel berdasarkan karakteristik tertentu yang dianggap mempunyai sangkut pautnya dengan karakteristik informan yang sudah diketahui sebelumnya dengan metode pengumpulan data, yaitu wawancara (interview) adalah percakapan antara periset, seseorang yang berharap mendapatkan informasi dan informan, seseorang yang diasumsikan mempunyai informasi penting tentang suatu objek (Kriyantono, 2007:96). Wawancara dimaksudkan untuk memperoleh keterangan, pendirian, pendapat secara lisan dari seseorang (informan) dengan berbicara langsung dengan orang tersebut.

Dalam penelitian ini, peneliti menggunakan wawancara semi struktur kepada subjek penelitian. Periset dimungkinkan untuk mengembangkan pertanyaan sesuai dengan situasi dan kondisi sehingga dimungkinkan mendapatkan data yang lengkap. Hasil dari wawancara yang dilakukan peneliti berupa tulisan. Dokumentasi bertujuan untuk mendapatkan informasi yang mendukung data penelitian. Dengan adanya dokumentasi maka peneliti akan mendapatkan informasi atau data yang mendukung (memperkuat data) tentang peranan humas pemda provinsi Bengkulu dalam menjalankan hubungan dengan pers. Teknik Analisis Data hasil penelitian melalui wawancara dan dokumentasi tersebut maka akan didapat data dan deskripsi bagaimana keadaan sesungguhnya mengenai peranan Humas Pemda Provinsi Bengkulu Dalam Menjalankan Hubungan Dengan Pers Pada Humas Khususnya pada Dinas Perhubungan Komunikasi Dan Informatika Provinsi Bengkulu.

\section{HASIL PENEL1TIAN DAN PEMBAHASAN}

\section{Menciptakan Hubungan dengan Pers}

Dalam penelitian ini, peranan Humas diartikan sebagai rangkaian kegiatan yang dilakukan oleh bagian Humas. Dalam menjalankan hubungan dengan pers, Humas seharusnya mampu menciptakan dan membina hubungan yang harmonis dengan pers.

Hasil penelitian menunjukkan bahwa sebanyak 5 informan dari Humas dan 1 informan dari pihak pers yaitu surat kabar Harian Rakyat Bengkulu, menyatakan 
bahwa untuk menciptakan dan membina hubungan pers yang baik adalah melalui cara kerja sama. Sebagai contoh apabila ada informasi/berita yang akan dipublikasikan, bidang kehumasan akan mengundang wartawan untuk menyampaikan informasi tersebut kepada masyarakat luas melalui Surat Kabar Harian Rakyat Bengkulu, TVRI Bengkulu atau RRI Regional I Bengkulu.

Namun demikian sebanyak 2 informan dari pihak pers yaitu TVRI Bengkulu (Agus Topo) dan RRI Regional I Bengkulu (Eni Sulistiawati), menyatakan bahwa Humas belum dapat menciptakan dan membina hubungan yang harmonis dengan pers. Humas sangat kurang mengisi acaraacara di media massa khususnya media elektronik, seperti TVRI, RRI dan media lainnya, apalagi melaksanakan kegiatan hubungan dengan pers dimana pihak pers/wartawan terlibat langsung dalam kegiatan Pemerintah daerah. Dengan demikian, dapat dikatakan bahwa Bidang Humas Dinas Perhubungan Komunikasi dan Informatika Propinsi Bengkulu dalam menciptakan dan membina hubungan dengan pers lebih banyak ke media cetak dibanding media elektronik. Padahal, hubungan pers tidak hanya terkait dengan media cetak saja melainkan pada semua bentuk media.

\section{Memahami dan Melayani Media}

Memahami dan melayani media dibagian Humas Dinas Perhubungan Komunikasi dan Informatika Provinsi Bengkulu, sudah dapat dikategorikan cukup baik. Hasil penelitian menunjukkan bahwa 5 informan dari Humas dan 2 informan dari pers, surat kabar Harian Rakyat Bengkulu (Riky) dan RRI Regional I Bengkulu, menjawab Humas dapat melayani dan memahami pers dengan baik, sedangkan 1 informan dari TVRI Bengkulu yang menyatakan bahwa Humas kurang memahami pers namun pelayanan yang diberikan kepada pers tetap baik. Dengan memahami dan melayani pers secara baik, Humas seharusnya mampu menjalin kerja sama dan hubungan timbal balik yang saling menguntungkan (Jefkins, 1992.101), tujuan pokok diadakannya hubungan dengan pers adalah menciptakan pengetahuan dan pemahaman.

\section{Menyediakan Salinan Naskah Berita}

Salinan naskah berita akan disediakan oleh bagian Humas apabila ada berita yang akan diterbitkan. 5 informan dari Humas serta 3 informan dari pihak pers, menjawab bahwa Humas tidak selalu memberikan salinan berita untuk diterbitkan, melainkan hanya diberikan pada saat-saat tertentu saja. Apabila bagian Humas mengundang atau memberitahukan para wartawan, kalau ada berita yang ingin dipublikasikan maka Humas tidak memberikan salinan naskah berita. Salinan yang diberikan itu berupa naskah dan foto berita.

\section{Menyediakan Fasilitas Verifikasi}

Humas seharusnya memberikan kebebasan kepada pers untuk memberikan verifikasi terhadap berita yang akan diterbitkan. Untuk melakukan verifikasi tersebut sebaiknya Humas memberikan fasilitas kepada pers untuk mempermudah melakukan verifikasi. Namun informan mengatakan bahwa tidak ada fasilitas verifikasi yang diberikan Humas kepada pers. Hasil penelitian dilapangan menunjukkan bahwa fasilitas verifikasi tidak ada sebanyak 4 informan dari Hurnas dan didukung 3 informan dari pihak pers, sedangkan 1 informan dari Humas menyatakan bahwa fasilitas yang diberikan Humas kepada pers yaitu berupa ruang konferensi pers.

\section{Kegiatan-Kegiatan Hubungan dengan Pers}


Kegiatan-kegiatan yang semestinya harus dilakukan Humas di lingkungan Dinas Perhubungan Komunikasi dan Informatika Propinsi Bengkulu, dalam rangka menciptakan dan membina hubungan yang baik dengan pers adalah sebagai berikut:

\section{Mengeluarkan Siaran Pers}

Dari hasil observasi di lapangan, jarang sekali terlihat di media massa siaran pers tentang kegiatan Pemerintah Daerah (Pemda) yang dikirim oleh Humas. Informan yang menyatakan bahwa Humas mengirim press release pada saat-saat tertentu saja (kadang-kadang), berjumlah 5 informan dari Humas serta 1 informan dari pihak pers yaitu surat kabar Harian Rakyat Bengkulu, dengan pertanyaan yang sama. Sedangkan 2 informan dari pers yaitu TVRI Bengkulu dan RRI Regional I Bengkulu tidak diberi pertanyaan karena siaran pers diberikan pada media cetak tidak media elektronik.

Siaran pers biasanya dikirim kepada media cetak, ini diungkapkan oleh Kasali (2000.170) dalam bukunya "Manajernen Public Relations" bahwa press release adalah segala bentuk informasi yang hendak disebarkan kepada pers, biasanya berbentuk media cetak. Apa yang mereka kirim atau yang diberikan Humas kepada para wartawan adalah sebuah naskah berita yang harus diterbitkan sesuai dengan keinginan mereka.

Naskah berita yang diberikan kepada pers, bukan berupa siaran pers (press release) yang siap untuk diterbitkan, dimana terdapat unsur-unsur jurnalistik sehingga menarik untuk dibaca dalam arti bahwa yang dikirimkan tersebut berupa lembaran siaran berita dengan kop surat, mengandung unsur $5 \mathrm{~W}+1 \mathrm{H}$, mencantumkan nama pejabat yang berwenang, berisi kejadian atau peristiwa menarik yang terjadi dilingkungan Pemerintah Daerah Provinsi Bengkulu. Dimana beritanya bersifat informatif.
Dalam penyampaian suatu pesan, Bidang Humas menyampaikan dengan bahasa yang singkat, tepat dan akurat begitu pun sifat informasinya. Dari hasil penelitian 3 orang informan mengungkapkan kalau dalam penyampaian pesan digunakan bahasa Indonesia yang jelas, menarik dan dapat dirnengerti serta dipahami oleh masyarakat luas, sedangkan 2 diantaranya tidak mengetahui masalah bahasa dalam penyampaian pesan karena staf Humas tidak pernah diajarkan bagaimana mengemas suatu pesan dan tidak pernah diadakannya pelatihan-pelatihan kehumasan atau pelatihan jurnalistik, sehingga tidak tahu bagaimana bahasa yang digunakan dalam penyampaian pesan.

Sifat berita yang disampaikan adalah berita yang penting, dinyatakan oleh 1 orang informan, 1 orang informan lagi mengatakan sifat pesan jelas, akurat dan menarik. Sedangkan 3 informan lagi tidak menjawab pertanyaan karena staf Humas tidak pernah diberitahu oleh pimpinan bagaimana sifat informasi yang seharusnya disampaikan oleh Humas. Ir. Ali Berti. MM cenderung bekerja sendiri terutama dalam penyampaian pesan kepada pers agar tidak terjadi salah penyampaian.

Mengeluarkan siaran pers yang dilakukan oleh Bidang humas provinsi bengkulu di benarkan oleh Kadis Perhubungan Komunikasi dan Informatika oleh Ir. Ali Berti.MM untuk menyampaikan Pesan, informasi atau berita tersebut untuk sampai ke pers disampaikan melalui proses. Dari sumber berita (Dinas Perhubungan Komunikasi dan Informatika Provinsi Bengkulu) dimuat oleh media massa dan dari media massa inilah pesan tersebut mencapai publik. Penyampaian pesan seperti ini disebut dengan komunikasi massa yaitu komunikasi melalui media massa. Seluruh informasi dengan jumlah sebanyak 5 orang memberikan keterangan, bahwa untuk 
mencapai publik pada umumnya pesan yang disampaikan Humas melalui pers.

\section{Melaksanakan Jumpa Pers}

Lima informan dari Humas serta 3 informan dari pers, menyatakan bahwa Humas sudah mampu melaksanakan jumpa pers dengan para wartawan. Humas Dinas Perhubungan Komunikasi dan Informatika Propinsi Bengkulu, sudah dapat melaksanakan kegiatan jumpa pers. Hal ini karena sudah adanya dana yang dimiliki Bidang Humas. sehingga kegiatan dalam hubungannya dengan pers sangat diperhatikan.

Dengan adanya jumpa pers yang dilakukan oleh bagian Humas kepada wartawan, ini diharapkan agar suatu kegiatan dapat dipublikasikan kepada masyarakat. Dalam forum seperti itulah pihak pers diberi kesempatan untuk bertanya guna menggali informasi sedalam mungkin.

\section{Mengadakan Wisata Pers}

Mengajak para wartawan ke suatu tempat, dimana terdapat kegiatan Pemerintah Daerah Propinsi Bengkulu, atau tempat terjadinya suatu peristiwa yang menarik dan layak untuk dipublikasikan menjadi suatu kegiatan Humas dalam menjalin hubungan dengan pers.

Kegiatan wisata pers ini sudah bisa dilaksanakan oleh bagian Humas Dinas Perhubungan Komunikasi dan Informatika Propinsi Bengkulu, hal ini didukung oleh pernyataan informan sebanyak 5 informan dari Humas dan 3 informan dari pers, bahwa Humas sudah mampu untuk mengadakan wisata pers karena adanya dana yang diberikan untuk rnelaksanakan kegiatan wisata pers. Apabila ada berita yang ingin diliput biasanya wartawan datang dengan sendirinya ke tempat kejadian atas undangan dari Bidang Humas, juga atas inisiatif sendiri para wartawan.

\section{Melakukan Wawancara Pers}

Wawancara pers merupakan salah satu cara yang dilakukan bidang Humas dalam mencapai penerbitan dan publikasi yang baik. 5 informan dari Humas dan 1 informan dari pers yaitu surat kabar Harian Rakyat Bengkulu, yang memberikan pernyataan bahwa Humas sering mengadakan wawancara pers. Sedangkan informan yang menyatakan bahwa Humas kurang sekali mengadakan wawancara berjumlah 2 informan dari pihak pers yaitu TVRI Bengkulu dan RRI Regional I Bengkulu, informan yang menentang pernyataan itu disebabkan karena Humas kurang sekali mengadakan pemberitaan melalui media elektronik melainkan hanya mengisi acara-acara formal dan pada saatsaat tertentu saja. Kegiatan ini sering dilakukan oleh Humas guna rnenyebarluaskan informasi atau beritaberita informasi pembangunan ma kepada masyarakat luas.

\section{Membuat Siaran Sanggahan}

Apabila terjadi hal-hal yang tidak sesuai atau menyimpang dari release yang diberikan oleh Humas, maka Humas akan melakukan sanggahan atau mengklarifikasi berita tersebut.

Humas melakukan siaran sanggahan apabila ada berita yang menyimpang dari yang sebenarnya. Dari pernyataan 5 informan dari Humas menjawab bahwa Humas melakukan kegiatan siaran sanggahan apabila terjadi pemberitaan yang menyimpang dari fakta yang nantinya akan menumbuhkan citra negatif dimata masyarakat. Dengan demikian menurut Ir. Ali Berti. MM akan mengadakan siaran sanggahan untuk menjaga citra Dishubkominfo Propinsi Bengkulu, di mata masyarakat serta rnenunjukkan bahwa Humas bertanggung jawab atas berita yang telah dimuat serta memberikan kebenaran yang ada. Sedangkan 1 informan dari pers yaitu surat kabar Harian Rakyat Bengkulu, menjawab tidak ada dengan alasan apa yang diterbitkan sesuai dengan berita yang dikirim Humas 
sehingga tidak ada yang perlu disanggah. Informan yang tidak diberikan pertanyaan tentang sanggahan berita ini ada 2 informan, yang berasal dari TVRI Bengkulu dan RRI Regional I Bengkulu. Hal ini dikarenakan siaran sanggahan ditujukan untuk menyanggah siaran pers yang dimuat di media cetak.

Membuat Sanggahan Berita apabila ada berita yang tidak benar

Sama halnya dengan siaran sanggahan, menyanggah berita juga merupakan tugas dari bidang Humas. Siaran sanggahan berbeda dengan sanggahan berita. Siaran sanggahan ditujukan untuk menyanggah kesalahan yang terdapat dalam siaran pers yang dibuat Humas. Sedangkan sanggahan berita ditujukan untuk beritaberita yang dimuat dalam media massa baik media cetak maupun elektronik.

Sanggahan berita dilakukan untuk menghindari tumbuhnya citra negatif terhadap instansi. Informan dari Humas yang berjumlah 5 orang mengatakan ada sanggahan berita sedangkan 3 informan dari pihak pers mengungkapkan bahwa tidak ada sanggahan berita yang dibuat Humas. Humas tidak pernah membuat sanggahan berita pada media elektronik, karena pada media elektronik Humas tidak pernah melakukan hubungan pers terutama dalam bidang pemberitaan. Sedangkan pada media cetak, diungkapkan oleh informan bahwa berita yang diterbitkan selalu dikonfirmasikan dengan sumber berita sehingga tidak ada berita yang perlu disanggah.

\section{Menyelenggarakan Penerbitan dan Publikasi}

Mengadakan siaran-siaran melalui radio dan Televisi, untuk kegiatan-kegiatan Pemda Provinsi Bengkulu sering kali Bidang Humas Dishubkominfo Provinsi Bengkulu dan tidak membedahkan baik media cetak maupun media elektronik, biasanya disampaikan langsung ke RRI dan TVRI melalui dialog Intraktif langsung sehingga adanya tanya jawab antara nara sumber dengan masyarakat yang bertanya langsung melalui bae telefon yang telah di siapkan. Bukan itu saja Bidang Humas juga bisa membuat rekaman tunda buat disiarkan pada waktu yang telah ditentukan. Selanjutnya mengisi rubrik-rubrik penting pers tidak kalah pentingnya juga Bidang humas juga sering mengisi rublik-rublik penting pers seperti undangan untuk dialog, mengisi info pembangunan di media cetak dan elektronik. Membuat Dokumentasi

Mengcover kegiatan upacara/kunjungan kerja/tarnu penting, menganalisa berita-berita, menyelenggarakan foto dokumen dan foto berita, membuat kliping berita. Setiap ada kegiatan upacara/kunjungan kerja/tamu penting adalah tugas Bidang Humas untuk rnengcovernya agar bisa dijadikan sebagai sebuah laporan atau dokumen. Bidang Humas selalu melaksanakan hal ini, demi kepentingan lembaga (Dishubkominfo Propinsi Bengkulu), demikian pula dengan menganalisa berita-berita, menyelenggarakan foto dokumentasi dan berita serta pembuatan kliping berita.

Bahan dokumentasi yang umumnya dipergunakan oleh suatu lembaga adalah foto, karena foto dapat mencerminkan kejadian sebenarnya. Foto dapat juga digunakan sebagai pendukung data dalam pemberitaan. Dengan foto, orang akan lebih merasa yakin bahwa apa yang dimuat ditulis berdasarkan fakta. Dalam setiap acara baik acara pormal maupun non formal. Bidang Humas selalu menyempatkan diri untuk mengambil fotonya. Baik itu berupa berita ataupun foto dokumentasi. Seluruh informan yang berjumlah 5 informan dari Humas mengatakan bahwa Humas selalu mengambil foto setiap ada kegiatan. Foto ini biasanya di masukkan kedalam album khusus kegiatan, untuk foto dan yang lainnya diberikan kepada pers untuk 
diterbitkan bersamaan dengan berita. Intinya untuk pelaksanaan foto dokumen dan foto berita Humas selalu siap karena pegawai Humas memang sering diidentikkan dengan juru foto.

Kegiatan rutin yang dilakukan Humas adalah pembuatan kliping berita, release. Bidang Humas selalu menerima surat kabar setiap harinya. 5 responden dari Humas menjawab terlaksana dengan sepenuhnya. Kliping ini disusun berdasarkan urutan tanggal dan setiap akhir bulan kliping ini dijilid dan diarsipkan. Berita yang dibuat kliping ini berasal dari surat kabar Harian Rakyat Bengkulu.

\section{Hasil Analisis Peranan Humas Pemerintah Daerah Provinsi Bengkulu dalam Menjalankan Hubungan dengan Pers}

Berdasarkan hasil analisis, wawancara dan observasi dilapangan, yang dilakukan penulis selama penelitian, dapat dijelaskan bahwa peranan Humas dalam menjalankan hubungan dengan pers bisa dikatakan kurang terleksana dengan baik. Hal ini terbukti dan terlaksananya sebagian kegiatan Humas Pemda, Dinas Perhubungan Komunikasi dan Informatika Propinsi Bengkulu, dalam melakukan hubungan dengan pers. Dari hasil wawancara menunjukkan bahwa sebanyak 5 informan dari Humas menyatakan bahwa Humas dapat menciptakan dan membina hubungan dengan pers. Dalam memahami dan rnelayani media, dibagian Humas pada Dishubkominfo Propinsi Bengkulu menunjukkan bahwa dari 5 informan dari Humas dan 2 informan dari pers menyatakan Humas dapat memahami dan melayani media, hanya 1 informan dari pihak pers yaitu TVRI Bengkulu yang menatakan Humas kurang memahami pers.

Dalam hal menyediakan salinan naskah berita, Humas tidak selalu memberikan salinan untuk diterbitkan melainkan hanya diberikan pada saat-saat tertentu saja. Hal ini dapat dilihat dari 5 informan dari Humas dan 3 informan dari pers. Kemudian didalam menyediakan fasilitas verifikasi, 4 informan dari Humas dan 3 informan dari pihak pers, menyatakan bahwa Humas tidak dapat memberikan fasilitas verifikasi, sedangkan 1 informan dari Humas menyatakan ada fasilitas verifikasi yang diberikan yaitu ruang konferensi pers.

Berdasarkan dari hasil observasi dilapangan, kegiatan-kegiatan yang dilakukan Bidang Humas Dishubkominfo Propinsi Bengkulu dalam rangka menciptakan dan membina hubungan yang baik dengan pers, seperti mengeluarkan siaran pers atau press prelease, dari 5 informan serta 1 informan dan pihak pers, menyatakan bahwa Humas tidak selalu mengeluarkan siaran pers melainkan pada saat-saat tertentu saja. Sedangkan 2 informan lainnya tidak diberikan pertanyaan karena siaran pers hanya diberikan pada media cetak dan media elektronik. Didalam pelaksanaan jumpa pers, sebanyak 5 informan dan 3 informan dari pers, menyatakan bahwa Bagian Humas sudah dapat melaksanakan kegiatan jumpa pers, hal ini karena sudah tersedianya dana yang dimiliki Humas dan kegiatan penting lainya.

Dalam hal mengadakan wisata pers, sampai saat ini Humas sudah mampu mengadakan wisata pers hal ini didukung dari hasil penelitian bahwa 5 informan serta didukung 3 informan dari pihak pers menjawab tidak ada. Ini disebabkan karena Bidang Humas Dinas Perhubungan Komunikasi dan Informatika Provinsi Bengkulu sudah mempunyai dana yang cukup dan biasanya wartawan datang sendiri ketempat kejadian atau undangan dari Bidang Humas.

Kemudian dalam melakukan wawancara pers Humas sering sekali melakukan, hal ini didukung dari pernyataan 
informan dari Humas yang berjumlah 5 informan dan 1 informan dari pihak pers yaitu surat kabar Harian Rakyat Bengkulu. Tetapi Humas lebih banyak mengadakan wawancara dengan media cetak dan elektronik. Selanjutnya didalam membuat siaran sanggahan, apabila terjadi hal-hal yang tidak sesuai atau menyimpang dari release yang diberikan oleh Humas maka Humas akan melakukan sanggahan atau mengklarifikasi berita tersebut. Pernyataan ini didukung oleh 5 informan dari Humas. Dalam hal membuat sanggahan berita apabila ada berita yang tidak benar informan dari Humas yang berjumlah 5 informan menyatakan ada sanggahan berita apabila ada berita yang tidak sesuai dengan fakta.

Sedangkan didalam menyelenggarakan penerbitan dan publikasi seperti, mengadakan siaran-siaran melalui radio dan televisi 5 informan dari Humas dan 2 informan dari pihak pers, menyatakan kurang terlaksana karena yang mengadakan siaran melalui radio dan televisi bukan bagian Humas tetapi bidang Dialog di Media Elektronik. Dalam hal mengisi rubnik-rubrik penting di pers 5 informan serta didukung oleh 1 informan dari pihak pers, yaitu surat kabar Harian Rakyat Bengkulu.

Kemudian didalam membuat dokumentasi, seperti rnengcover kegiatan upacara/kunjungan kerja/ tamu penting, Humas selalu melaksanakan dengan sepenuhnya hal ini didukung oleh pernyataan 5 informan dari Humas. Dalam hal menganalisa berita-berita 3 informan dari Humas menyatakan Humas sudah menganalisa berita-berita yang dimuat terutama mengenai kebenaran isi berita. Dalam setiap acara baik acara formal maupun non formal, Humas selalu rnenyempatkan diri untuk mengambil fotonya, baik berupa foto berita ataupun foto dokumen, hal ini didukung oleh pernyataan seluruh informan dan Humas yang berjumlah 5 informan.
Kegiatan rutin lainnya adalah pembuatan kliping berita, release beritaberita yang menyangkut rnasalah informasi pembangunan dan lainnya di surat kabar terutama kegiatan Pemda Propinsi Bengkulu, diambil atau digunting dan dibuat keliping. Hal ini didukung oleh pernyataan dari seluruh responden yang berjumlah 5 responden dari Bidang yang menyatakan terlaksana sepenuhnya.

\section{KESIMPULAN DAN SARAN}

\section{Kesimpulan}

Berdasarkan dari hasil penelitian yang dilakukan, maka dapat disimpulkan sebagai berikut, Peranan Humas Pemerintah Daerah Provinsi Bengkulu Pada Dinas Perhubungan Komunikasi dan Informatika Provinsi Bengkulu, dalam menjalankan hubungan dengan pers dikategorikan baik. Baiknya Peranan Bidang Humas pada Dinas Perhubungan Komunikasi dan Informatika Provinsi Bengkulu dapat ditunjukkan oleh terlaksananya sebagian besar dari rangkaian kegiatan seperti, menciptakan hubungan dengan pers, melayani dan memahami media, wawancara pers, siaran sanggahan, mengisi rublik-rublik penting di pers dan membuat dokumentasi, yang dilakukan oleh Bidang Humas Dinas Perhubungan Komunikasi dan Informatika Provinsi Bengkulu dalam menjalankan hubungan dengan pers.

\section{Saran}

Hubungan yang seharusnya terjalin antara Humas dan Pers adalah hubungan timbal balik yang saling menguntungkan. Agar tercipta hubungan pers yang baik, disarankan kepada Bidang Humas agar kegiatan yang belum terlaksana sampai saat ini dapat dilaksanakan diwaktu mendatang karena belum berjalan dengan baik.

Agar kegiatan kehumasan terutama dalam menjalankan hubungan dengan pers 
dapat dilaksanakan dan dimengerti sepenuhnya oleh Pegawai Humas, maka sebaiknya staf Humas menambah pengetahuan mereka dalam bidang kehumasandengan adanya pelatihanpelatihan bidang kehumasan serta bukubuku kehumasan untuk menambah pengetahuan para pegawai humas. Dengan pelatihan-pelatihan dan buku-buku kehumasan diharapkan agar nantinya staf humas dapat memahami tugas-tugas yang seharusnya dilakukan oleh Humas. Terlaksananya tugas/kegiatan Humas berarti terlaksana pula sebagian tugas lembaga, serta merasa bertanggung jawab atas pekerjaan yang seharusnya dipikul oleh mereka.

\section{DAFTAR PUSTAKA}

Ahmadi, Abu, H. 1990. Kamus Lengkap Sosiologi. CV. Aneka Solo.

Abdullah, Aceng. 2000, Perss Relation : kiat Berhubungan Dengan Pers.

PT. Remaja Rosdakarya Bandung.

Abdurrahman, Oemi. 1993, Dasar-Dasar Public Relation. PT. Aditya Bakti Bandung.

Assegaf, Djafar H. 1980. Hubungan Masyarakat dalam Praktek. Ghalia indonesia Jakarta.

Coulson, Colin-Thomas. 1993. Perss Relation : Pedoman Praktis Untuk PR. Bumi Aksara Jakarta.

Effendy, Onong Uchjana. 1989. Kamus Komunikasi. CV. Mandar Maju Bandung.
Effendy, Onong Uchjana. 1993. Human Relations Dan Public Relation. CV. Mandar Maju Bandung.

Bonar, S.K. 1993. Hubungan Masyarakat Modern. Rineka Cipta . Jakarta.

Kuswandi, wawan, 1993, Komunikasi Massa Sebuah Analisis Media Televisi. Rineka Cipta: Jakarta

Krisyanto, rahmat, 2006, Teknis Praktek Riset Komunikasi, Berkah Ilahi: Bengkulu.

Kamaruddin. 1994. Eksiklopedia Manajemen. Bumi Aksara Jakarta.

Poerwadarminta, W.J.S. 1985. Kamus Umum Bahasa Indonesia. Balai Pustaka Jakarta

Muda, Iskandar Dedy. 2003. Jurnalistik Televisi Menjadi Reporter Professional. PT Remaja Rosdakarya: Bandung

Rahmat, Jalaludin, 1998, Metode Penelitian Komunikasi, Remaja Rosdakarya: Bandung

Wahyudi, JB, 1996, Dasar-Dasar Jurnalisitik Radio Dan Televisi, Pustaka Utama Grafiti: Jakarta

Wahyudi, JB, 1983, Jurnalisitik Televisi Tentang Sekitar Siaran Berita, Pustaka Utama Grafiti: Jakarta.

Wijaya, A,W, 1993, Komunikasi dan Hubungan Masyarakat, Bumi Aksara: Jakarta

Wahyu dan Mohammad Masduki. 1990. Petunjuk Praktis Membuat Skripsi. Usaha Nasional surabaya. 
Anggoro Linggar, M 2000. Teori dan profesi Kehumasan. Bumi Aksara. Jakarta.

Rahcmadi, F 1994. Publik Relations dalam Teori dan Praktek: Aplikasi dalam Badan Usaha Swasta dan Lembaga Pemerintah. PT. Gramedia Pustaka Utama. Jakarta.

Tunggal, Amin Widjaja, AK. 1996. Kamus Manajemen Sumber Daya Manusia
Dan Perilaku Organisasi. Rineka Cipta Jakarta.

Tim Penyusun Kamus Pembinaan dan Pengembangan Bahasa Departemen Pendidikan dan Kebudayaan. 1991. Kamus Besar Bahasa Indonesia. Balai Pustaka Jakarta. 